軽金属 第64巻 第 11 号 (2014)，542-550

$$
\begin{gathered}
3 \text { 次元アトムプローブによるアルミニウム合金中の } \\
\text { ナノ組織解析 }
\end{gathered}
$$

\author{
廣澤 渉一 * . 小椋 智**. 芹澤 愛*** \\ 小宮 良樹 $* * * *$. 里 達雄 $* * * * *$
}

\begin{abstract}
Journal of The Japan Institute of Light Metals, Vol. 64, No. 11 (2014), 542-550
(C) 2014 The Japan Institute of Light Metals
\end{abstract}

\title{
Nano-scale microstructural analysis of aluminum alloys by three-dimensional atom probe
}

\author{
Shoichi HIROSAWA*, Tomo OGURA**, Ai SERIZAWA*** \\ Yoshiki KOMIYA**** and Tatsuo SATO*****
}

Keywords: atom probe, aluminum alloy, microstructure, nanocluster, precipitation

\section{1.はじめに}

3 次元アトムプローブ（three-dimensional atom probe, 以下 3DAP と呼ぶ）は，材料内部の元素分布を原子レベルで3次 元的にイメージングできる微細領域分析装置であり，1988 年にオックスフォード大学のグループ1) によって初めて実 用化されて以来，多くの有益な知見をもたらしている。これ は, 3DAPが高い空間分解能（分析深さ方向で $<1 \mathrm{~nm}$, 分析 面内方向で数 nm) と優れた質量分解能（後述するマスプロ ファイルの半值幅で>500）を併せ持つためであり，試料内 部を実空間で解析できるという，他の分析装置にはないユ ニークな特徵も有している。

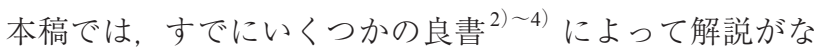
されている3DAPを用いた分析法（3DAP分析）について, その原理や特徵を概説し, 分析時ならびにデー夕解析時に生 じうるアーチファクト（偽所見）についても注意を喚起した 後に，これまでに著者らが行ってきた各種アルミニウム合金 材料のナノ組織解析結果の例を紹介する。

\section{2. 分析の手順と原理}

\section{1 試料作製}

3DAP分析を行うためには，先端の局率半径が $10 〜 100 \mathrm{~nm}$ 程度の針状試料を作製する必要があり，電解研磨法や収束イ オンビーム (FIB) 法 $^{3)}$,4) が用いられることが多い。特に後 者は，分析したい領域を針先端から数 $10 \mathrm{~nm}$ 以内の位置に選 択的に配置するのに有効であり, 多層薄膜界面や異相界面,
結晶粒界近傍のナノ組織解析には不可欠な手法となってい $3^{5), 6)}$ 。

\section{2 FIM 観察}

3DAP装置の多くには, 分析を行う超高真空チャンバ内に $\mathrm{He}$ や $\mathrm{Ar}, \mathrm{Ne}$ などのイメージングガスを導入するためのガス ラインが併設されており, 分析を行う前に電界イオン顕微 鏡（FIM）像を観察することで, 試料表面の酸化膜の除去な らびに分析方位，領域の選択が可能である。図1(a)，(b) は, $\mathrm{fcc}$ 構造をもつ針状試料先端の原子配列モデル（ボールモデ ルと呼ばれる） ${ }^{2)}$ および純アルミニウムのFIM像である。図 1 (a) で白く示された試料表面の突出した原子位置（エッジ やキンクに対応する）で高電界が生じ，イメージングガスが 優先的にイオン化して (電界イオン化現象), 蛍光板上に同 心円状の輝点が形成される（図 1(b))。そして, この試料原 子の配列を投影した輝点の対称性から, 試料先端の結晶学的 方位を同定し, 3DAP分析に適した低指数面近傍の分析領域 を選択する（例えば, 図1(b) に四角で示した領域)。なお, 近年開発された広角（wide-angle）型アトムプローブ装置を 用いる場合には, 必ずしもFIM観察を行わなくても, 後述す るアトムマップから試料の結晶学的方位を知ることも可能で ある（図 $1(\mathrm{c}))$ 。

\section{3 3DAP分析}

一方, 3DAP分析を行う場合には, 電界蒸発現象と呼ばれ る高電界下における試料原子そのもののイオン化現象を利用 する。すなわち，FIM観察で用いたイメージングガスを十分 に排気した後に，定常電圧に15〜25\%（この割合をパルスフ

*横浜国立大学大学院工学研究院（=240-8501 神奈川県横浜市保土ヶ谷区常盤台 79-5)。Department of Mechanical Engineering and Materials Science, Yokohama National University (79-5 Tokiwadai, Hodogaya-ku, Yokohama-shi, Kanagawa 240-8501). E-mail: hirosawa@ynu.ac.jp

**大阪大学大学院工学研究科 (吹田市)。Division of Materials and Manufacturing Science, Graduate School of Engineering, Osaka University (Suita-shi, Osaka).

****芝浦工業大学工学部材料工学科 (東京都)。Department of Materials Science and Engineering, Shibaura Institute of Technology (Koto-ku, Tokyo).

****日本大学理工学部航空宇宙工学科 (船橋市)。Department of Aerospace Engineering, Nihon University (Funabashi-shi, Chiba).

*****東京工業大学精密工学研究所 (横浜市)。Precision and Intelligence Laboratory, Tokyo Institute of Technology (Midori-ku, Yokohama). 受付日：平成26年6月4日＼cjkstart受理日：平成26年7月 11 日 


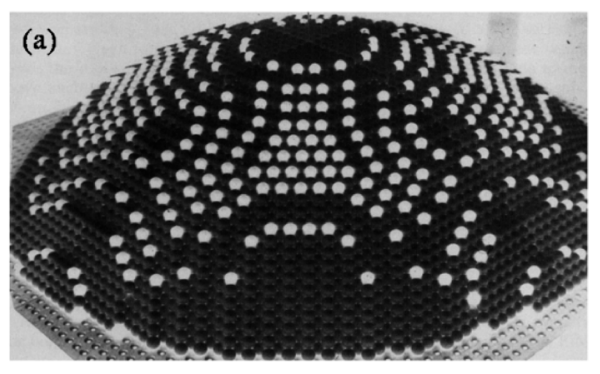

(b)
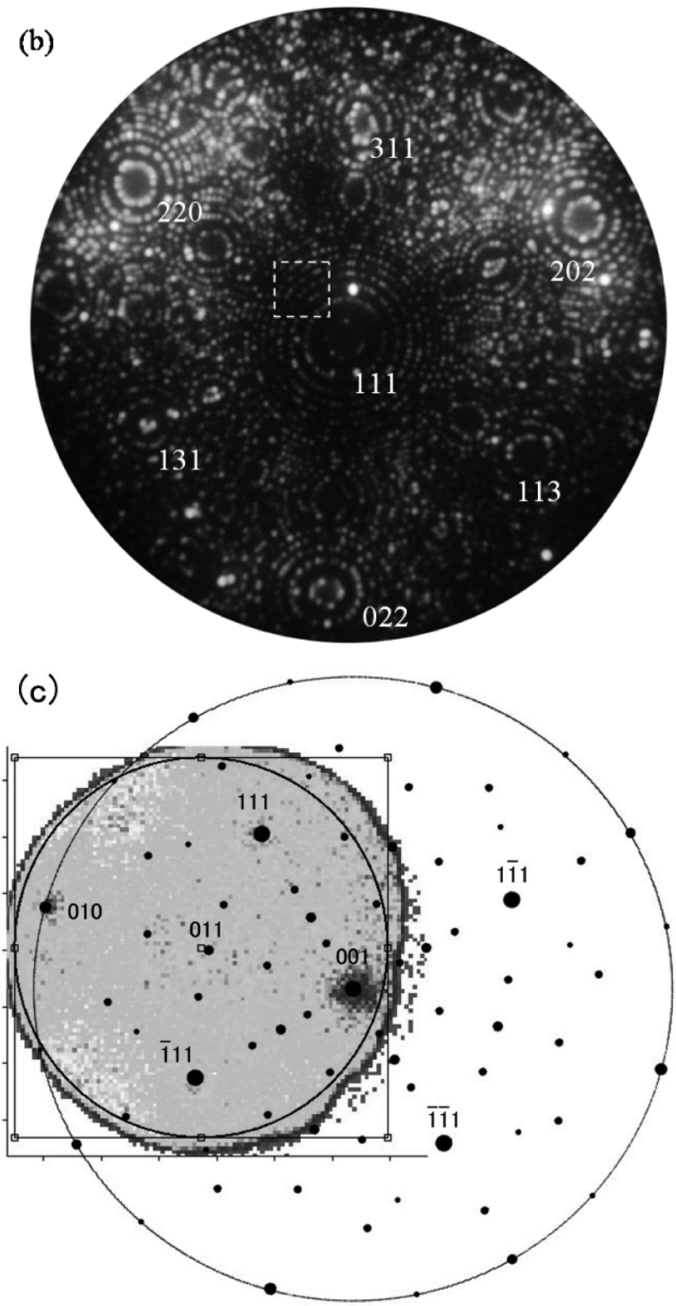

図1 fcc 構造をもつ針状試料先端のボールモデル ${ }^{2)}$ (a) と純アルミニウムの FIM像 (b)。広角型アトムプ ローブの場合には, アトムマップ (c) から結晶 方位を知ることもできる

ラクションと呼ぶ）のパルス電圧を重ねて印加し, 試料表面 の原子を断続的にイオン化させる。そして, 図2に示した飛 行経路を通った各イオンを位置敏感型検出器によって検出 し, パルス電圧が印加されてイオンが試料表面を飛び出して から, 検出器に到達するまでの飛行時間をもとに, イオンの 質量すなわち原子種 (元素) を同定する。さらに, 電界蒸発 現象が試料表面のエッジやキンクの位置から規則的に起こる 性質を利用して，イオンの到達場所を示す2次元マップに適 宜深さ方向の座標を与え, 最終的に解析ソフトウェアを用い て数百〜数千万イオンにもなる 3 次元アトムマップを構築す る。ただし, その際以下に挙げるようなアーチファクトが生 じうることを認識し, 細心の注意を払って解析を行うことが 重要となる。

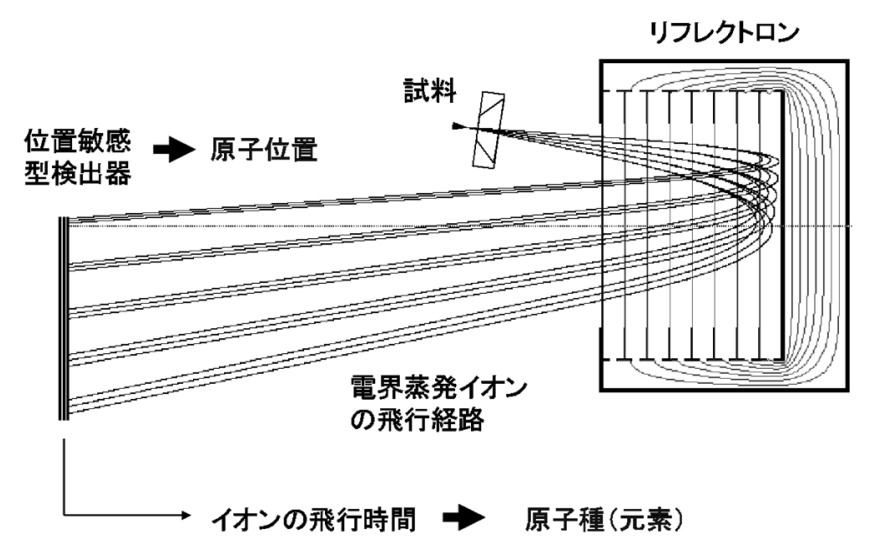

図2リフレクトロンを用いたエネルギー補償型3DAP 装置のレイアウトおよび分析原理

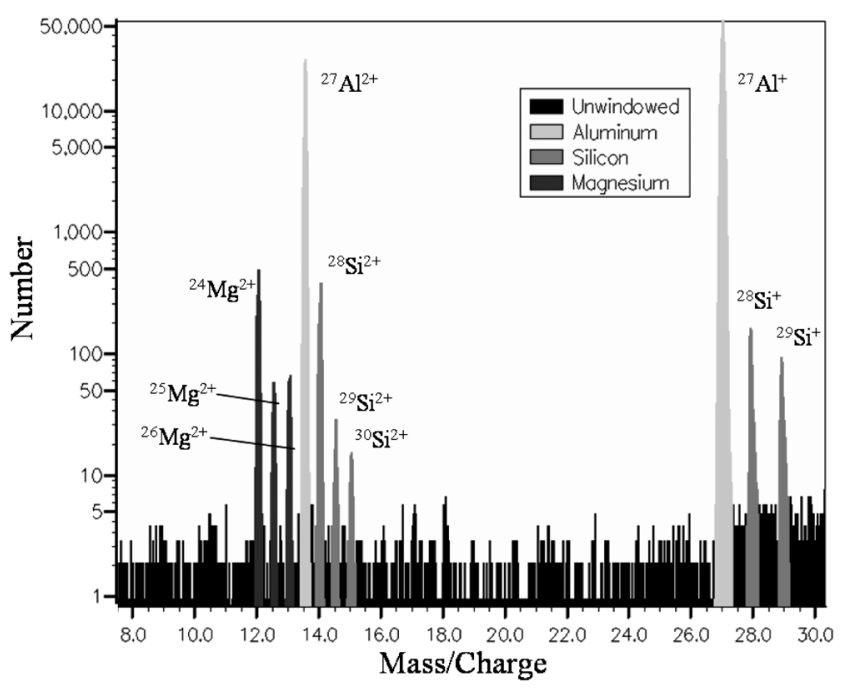

図3 Al-Mg-Si合金のマスプロファイル

\section{3. データ解析とアーチファクト}

\section{1 合金組成}

3DAP分析結果の解析は, 通常以下の手順で行う。まず, 分析データをコンピュータに読み込んだ後に, 検出された全 イオンの質量/電荷比の頻度分布曲線（マスプロファイルと 呼ばれる）を描き，解析者が各ピークに対応する元素をひと つずつ指定して，検出したイオンの原子種を同定する（ウィ ンドウをかけるという)。図3は,リフレクトロンを用いた エネルギー補償型アトムプローブ（図2）によって得られた $\mathrm{Al}-\mathrm{Mg}-\mathrm{Si}$ 合金のマスプロファイルにウィンドウをかけた例

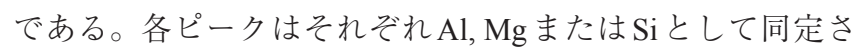
れており，原子番号が並んだこれらの元素の同位体がすべ て分離できるほど質量分解能が高いことがわかる（半值幅 で>500)。また，3DAP分析では Liなどの軽元素も同定でき るため, エネルギー分散型X線分析 (EDX) などでは検出, 分離が困難な元素を含む合金であっても，組成の定量評価が 可能である。さらに, 合金組織が比較的均一な場合には（例 えば, 過飽和固溶体や濃度変動が小さい相分解初期組織な ど），ウィンドウをかけた後の分析体積内の合金組成をバル ク組成と比較することで, 分析条件（分析温度およびパルス フラクション）が適切であったか否かを判断することがで 

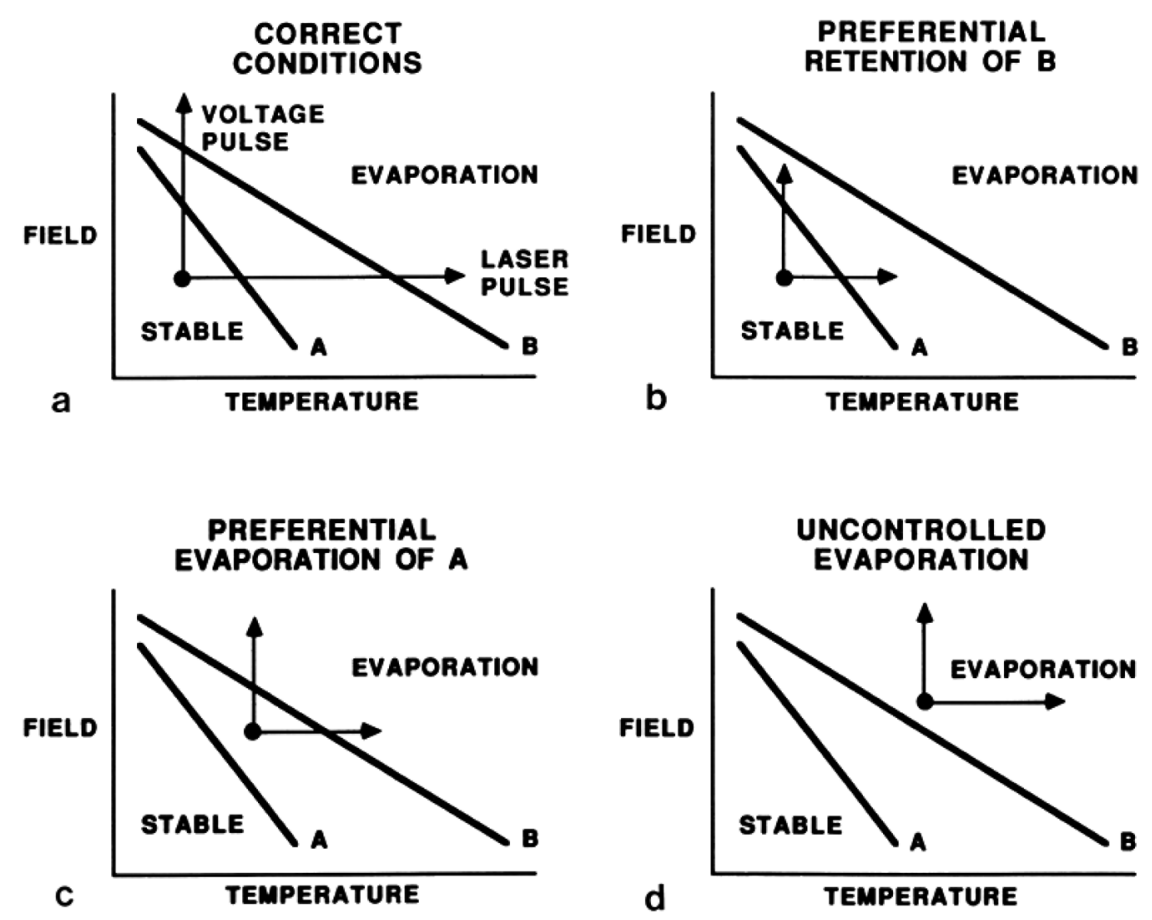

図4 A-B二元合金の電界蒸発現象に及ぼす分析温度ならびに電界強度の影響 ${ }^{2}$ 。電界強度 $F$ は $F=V / k r$ 式で印加電圧 $V$ と 関係付けられる（ここで， $k$ は定数 $(\approx 5), r$ は試料の曲率半径 $)$

きる。図4に, A-B二元合金で生じる電界蒸発現象の分析条 件依存性を模式的に示す ${ }^{2)}$ 。パルス電圧印加時に A, B 両原子 が同時に電界蒸発するためには, 図 $4 \mathrm{a}$ の縦矢印のような分 析温度と電界強度が必要であり， B 原子がまったく電界蒸発 しない（図4b)，A原子が優先的に電界蒸発する（図4c）ま たは印加電圧に関係なく常に両原子が電界蒸発する（図4d) ような分析条件を避けなくてはならない。

表 1 に, 3DAP分析時およびデー夕解析時に生じうるアー チファクトとその原因, 対策法を示す。分析条件の最適化の ほかにも，アーチファクトを除去または軽減するための様々 な対策や検証が必要であり, 例えば図 3 の各ピークの大きさ を, 自然界に存在する同位体の存在比と比較することで, 分 析チャンバ内の残留水素ガスの影響を確かめることができ る（すなわち，真空度が低いと ${ }^{28} \mathrm{Si}^{+}$と同じ質量/電荷比の位 置に ${ }^{28} \mathrm{AlH}^{+}$のピークが重なり，合金組成や $\mathrm{Si}$ の同位体比に ずれが生じてしまう)。また，装置に不可避的に入り込む電 気的ノイズの影響に関しても，ウインドウがかからなかった イオン数の割合を評価することで，その分析が高い精度で行 われたか否かを判断することが可能である（例えば，図3で ウインドウがかからなかった電気的ノイズに起因するバック グラウンドは，全検出イオン数の高々 $1.5 \%$ 程度であり，装 置に組込まれたプリアンプが最適に設定されていたことを示 唆している)。

\section{2 アトムマップ}

次に，得られた各イオンの原子種ならびに座標の情報をも とに，アトムマップを構築する手順について説明する。アト ムマップを正しく描写するためには, 分析深さ方向のスケー リングが重要であるが, 著者らが用いている解析ソフトウェ アでは, (1)印加電圧 $10 \mathrm{kV}$ における試料先端の局率半径, (2) コンプレッションファクタ²), (3) $1 \mathrm{~nm}^{3}$ 当たりの試料内の原 子数, および(4)検出効率（リフレクトロンメッシュや検出器
表 $13 \mathrm{DAP}$ 分析時およびデー夕解析時に生じうるアー チファクトとその原因, 対策法

\begin{tabular}{|c|c|c|c|}
\hline \multicolumn{2}{|c|}{ アーチファクト } & \multirow{2}{*}{\begin{tabular}{|c|c|}
$|c|$ \\
原因 \\
分 析 条 件 の不 \\
適 (温度, パルス \\
フラクションなど)
\end{tabular}} & \multirow{2}{*}{\begin{tabular}{l}
\multicolumn{1}{c}{ 対策法 } \\
既知の合金組成をも \\
試料を分析し, 最適化 \\
する
\end{tabular}} \\
\hline \multirow{6}{*}{ 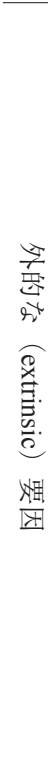 } & 合金組成のずれ & & \\
\hline & 同位体比のずれ & \multirow{2}{*}{$\begin{array}{l}\text { 試料原子が分析 } \\
\text { チャンバ内の残留 } \\
\text { 水素ガスと結合し } \\
\text { て, 電界蒸発する } \\
\text { ため }\end{array}$} & \multirow{2}{*}{ 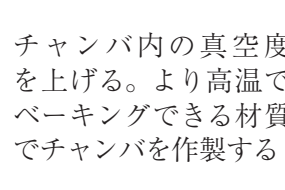 } \\
\hline & $\begin{array}{l}\text { 合金元素以外の } \\
\text { 元素の検出 }\end{array}$ & & \\
\hline & 検出効率の低下 & \multirow{2}{*}{$\begin{array}{l}\text { 電気的ノイズの混 } \\
\text { 入 }\end{array}$} & \multirow{2}{*}{ 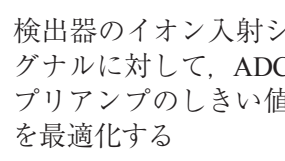 } \\
\hline & $\begin{array}{l}\text { 質量分解能の低 } \\
\text { 下 }\end{array}$ & & \\
\hline & $\begin{array}{l}\text { 分析体積のス } \\
\text { ケーリング }\end{array}$ & $\begin{array}{l}\text { 解析パラメータの } \\
\text { 設定不適（試料 } \\
\text { 先端の局率半径, } \\
\text { コンプレッション } \\
\text { ファクタ, 検出効 } \\
\text { 率) }\end{array}$ & $\begin{array}{l}\text { 分析深さ方向に垂直な } \\
\text { 原子面の面間隔を文献 } \\
\text { 值と比較し, 最適化す } \\
\text { る }\end{array}$ \\
\hline \multirow{3}{*}{ 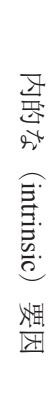 } & $\begin{array}{l}\text { 分析面内方向の } \\
\text { 空間分解能の低 } \\
\text { 下 }\end{array}$ & $\begin{array}{l}\text { 電界蒸発時に生じ } \\
\text { る蒸発収差 }\end{array}$ & $\begin{array}{l}\text { できるだけ低指数面 } \\
\text { ポールの中心を避けて } \\
\text { 分析する }\end{array}$ \\
\hline & $\begin{array}{l}\text { 析出物の形状, } \\
\text { サイズ, 組成の } \\
\text { ずれ }\end{array}$ & $\begin{array}{l}\text { 元素固有の電界蒸 } \\
\text { 発強度の違い (局 } \\
\text { 所拡大効果) })^{2), 3)}\end{array}$ & $\begin{array}{l}\text { 例 えば, Blavetteらの } \\
\text { 補正法 }^{7)} \text { 用いて真の } \\
\text { 析出物の情報を引き出 } \\
\text { す }\end{array}$ \\
\hline & 同位体比のずれ & $\begin{array}{l}\text { 同じ質量/電荷比 } \\
\text { をもつ元素の存在 }\end{array}$ & 分離不可能 \\
\hline
\end{tabular}




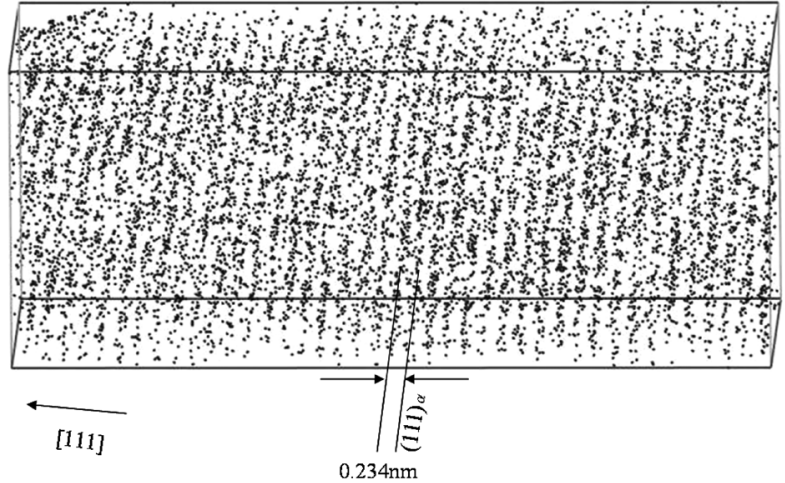

図 $5[111]_{\alpha}$ 方向から分析した純アルミニウムのアトム マップ

前面のマルチチャンネルプレートの有効面積率のために失わ れるイオンを差し引いた分析効率）の4つを解析パラメータ として入力する。このうち(2), (3)については, 装置のレイア ウトならびに分析する試料によって決まる值であり，アルミ ニウム合金の場合には，アルミニウムの原子充填密度〜 60 個 $/ \mathrm{nm}^{3}$ を(3)の值として入力する。一方，(1)については，別 途に透過型電子顕微鏡（TEM）などで実測した曲率半径を 用いるとよいが，同じ合金でも試料先端の方位によって若干 局率半径が異なる点には注意が必要である。さらに, 評価が 困難な(4)については，アトムマップで描かれる分析深さ方 向に垂直な原子面の間隔が，文献值と等しくなるよう值を 調整するため，通常 $50 \%$ 前後の值を用いることが多い。図 5 は，図1(b) の四角で示した（111）極付近を分析して得られ た純アルミニウムのアトムマップである。[111 $]_{\alpha}$ 方向に垂直 に一原子層ずつ $\mathrm{Al}$ 原子が配列しているのが観察され, 解析 パラメータの最適化によって，その間隔が $(111)_{\alpha}$ 面の面間 隔 $(d=0.234 \mathrm{~nm})$ と等しくなっていることがわかる。そのた め, 3DAPの空間分解能は, 分析深さ方向ではサブナノメー トルオーダであり, 分析面内方向でも, 電界蒸発時に生じる

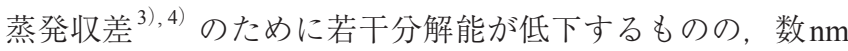
程度であると考えられている。なお，約 50\%程度という検 出効率からもわかるように，アトムマップでは実際に試料内 部に存在する原子の約半分しか描写されておらず，そのため 試料の結晶構造や原子空孔などの情報を引き出すことは極め て困難となっている。

\section{3 ナノ組織を特徵付ける各種組織因子}

3DAPは，試料内部のナノクラスタやナノ析出物（例えば Guinier-Preston（GP）ゾーン）などの溶質原子集合体を検出 することができ，表2に示すような合金内部のナノ組織を特 徵付ける各種組織因子を定量評価することが可能である。そ こで以下では，これまでに著者らが行ってきた各種アルミニ ウム合金材料のナノ組織解析結果の例を挙げ，様々な評価法 によって得られた組織因子を順に紹介する。

\section{4. ナノ組織解析結果の例}

\section{4. $1 \mathrm{Al}-\mathrm{Zn}$ 合金のナノ組織解析}

典型的な二相分離型の相分解挙動を示す $\mathrm{Al}-\mathrm{Zn}$ 合金の相分 解初期に形成する溶質集合体に着目し, その形成一成長過程 を3DAPで解析した。図6に，Al-4.9 at \%Zn 合金を $293 \mathrm{~K} て ゙$ 時 効した際の $\mathrm{Zn}$ 原子のアトムマップを示す ${ }^{8)}$ 。TEMでは検出

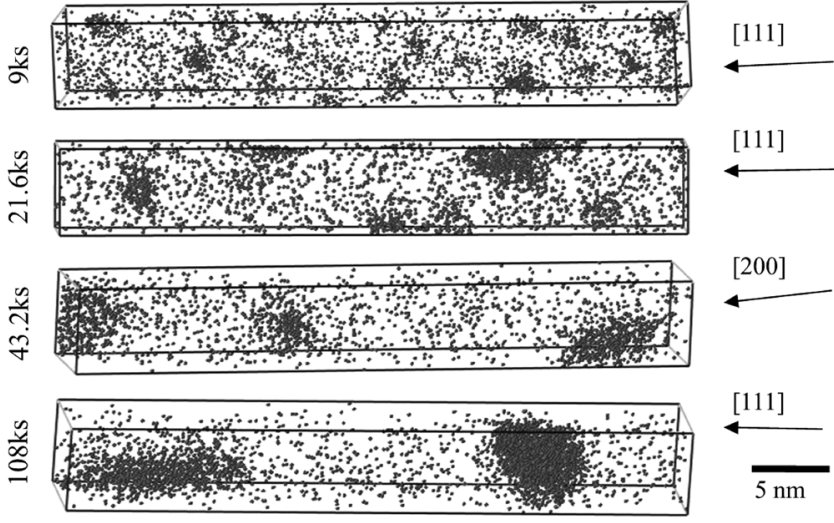

図6 Al-4.9at\%Zn 合金を $293 \mathrm{~K} て ゙$ 時効した際のアトム マップ。Zn原子を黒点で表しており，見やすさの ため $\mathrm{Al}$ 原子は描写していない ${ }^{8)}$

表2 合金のナノ組織を特徵付ける組織因子とその評価法

\begin{tabular}{|c|c|c|}
\hline \multicolumn{2}{|r|}{ 組織因子 } & 評価法 \\
\hline \multirow{7}{*}{$\begin{array}{l}\text { ナノクラス } \\
\text { タ・ナノ析 } \\
\text { 出物 }\end{array}$} & サイズ (平均, 分布) & アトムマップ, 相関関数 \\
\hline & $\begin{array}{l}\text { 数密度, 平均粒子間 } \\
\text { 距離 }\end{array}$ & アトムマップ, 相関関数 \\
\hline & 体積率 & アトムマップ \\
\hline & 形状 & $\begin{array}{l}\text { アトムマップ, 等濃度曲 } \\
\text { 面表示 }\end{array}$ \\
\hline & 組成 & $\begin{array}{l}\text { アトムマップ, 濃度プロ } \\
\text { ファイル, ラタタープロット }\end{array}$ \\
\hline & 内部構造（規則構造） & $\begin{array}{l}\text { アトムマップ, } 2 \text { 元分割表 } \\
\text { 解析, 動径分布関数 }\end{array}$ \\
\hline & $\begin{array}{l}\text { 界面構造（組成変化 } \\
\text { 幅，偏析） }\end{array}$ & $\begin{array}{l}\text { 濃度プロファイル, ラダー } \\
\text { プロット, 等濃度曲面表示 }\end{array}$ \\
\hline \multirow{2}{*}{ その他 } & 母相中の残留溶質濃度 & アトムマップ \\
\hline & 原子間の相関 & $\begin{array}{l}\text { 度数分布解析, } 2 \text { 元分割表 } \\
\text { 解析, 動径分布関数 }\end{array}$ \\
\hline
\end{tabular}

が困難な数 $\mathrm{nm}$ 程度の溶質集合体が時効初期から形成し, 時 効時間の経過とともに成長していることがわかる。図7に, 溶質集合体内部の Zn 濃度のサイズ依存性を示す。ここで, $\mathrm{Zn}$ 濃度は空間分解能が最も高い分析深さ方向に平行な $\mathrm{Zn}$ 濃 度プロファイルから算出し, 一方サイズは溶質集合体と等 体積の球相当直径 $d$ として評価した ${ }^{8)}$ 。図 7 より, 時効時間 にかかわらず, $d$ が小さい場合にはZn 濃度のばらつきが大き く, $d>\sim 7 \mathrm{~nm}$ でほぼ一定の Zn 濃度（～60 at $\% \mathrm{Zn} ）$ となるこ とがわかる。すなわち， $d>\sim 7 \mathrm{~nm}$ の大きさをもつ溶質集合 体は，一定の内部Zn 濃度をもって準安定に存在する GP ゾー ンとみなせるのに対して, $d<\sim 7 \mathrm{~nm}$ の大きさをもつ溶質集 合体は，未だ固有の溶質濃度をもたないナノクラス夕と定義 することができる。このように，3DAP分析はX線小角散乱 法（SAXS）で得られる平均化された值とは異なり，溶質集 合体個々のサイズや濃度を定量評価できるため, ナノクラス タと GPゾーンを明確に区別することも可能である。 


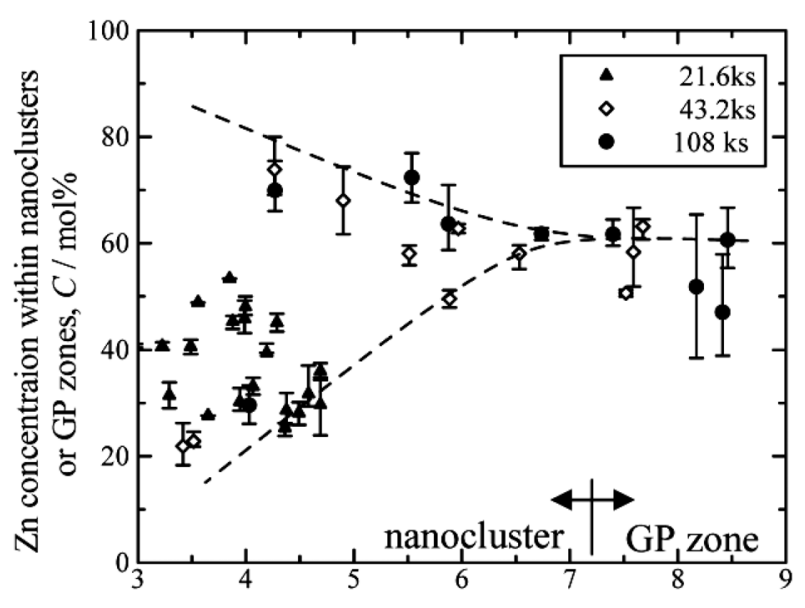

Equivalent sphere diameter, $d / \mathrm{nm}$

図7 Al-4.9at \%Zn 合金を $293 \mathrm{~K} て ゙$ 各時間時効した際の溶 質集合体内部の Zn 濃度のサイズ依存性 ${ }^{8)}$

\section{2 Al-Mg-Si合金のナノ組織解析}

自動車用ボディパネル材料として使用されている $\mathrm{Al}-\mathrm{Mg}-$ $\mathrm{Si}$ 系合金は，製造工程中の焼付け塗装処理時に耐力が増加 するベークハード性（BH性）を有するが，溶体化・焼入れ 後に室温で保持すると，自然時効の経過とともにその後の BH性が低下する，いわゆる二段時効の負の効果を示すこと が知られている。一方, その工業的な解決法の一つとして, $373 \mathrm{~K}$ 程度の予備時効処理が有効であるとされており ${ }^{9)}$ ，両 時効温度で形成する 2 種類のナノクラス夕 (クラス夕 (1), クラスタ (2)) に関する詳細な知見が求められていた。

図 8 に, 過剩 $\mathrm{Si}$ 型 $\mathrm{Al}-0.95 \% \mathrm{Mg}-0.81 \mathrm{at} \% \mathrm{Si}$ 合金を室温お よび $373 \mathrm{~K} て ゙$ 各時間時効した際のアトムマップを示す ${ }^{10)} 。$ Maximum separation 法 $^{11)}$ を用いたクラスタ解析を行うこと で，ナノクラスタを構成している $\mathrm{Mg}$ や $\mathrm{Si}$ 原子と，母相中に 固溶しているそれらを区別することができ，TEMでは観察 できないこれら微小なナノクラス夕が, 両時効温度における 硬化の原因になっていることが示唆される。図9に，時効時 間の経過に伴う両ナノクラスタの組成およびサイズ変化を示 す（なお，クラスタの構成要素としては，他に $\mathrm{Al}$ 原子や空 孔などが考えられるが, 本解析では組成を $\mathrm{Mg} / \mathrm{Si}$ 比, サイズ を $\mathrm{Mg}+\mathrm{Si}$ 原子数と定義して評価を行った ${ }^{10)}$ 。室温で形成す るクラス夕（1）は， $7.88 \times 10^{4} \mathrm{ks}$ という長時間時効後もほと んどサイズが増加せず，依然として組成の大きなばらつきを 示すのに対し（図9(a)），373Kで形成するクラスタ（2）は， 時効時間の経過に伴って著しいサイズの増加，およびそれに 伴う $\mathrm{Mg} / \mathrm{Si}$ 比の収束を起こすことがわかる（図 9(b))。その 後の詳細な解析により, クラス夕（1）は $433 \mathrm{~K} の \mathrm{BH}$ 温度で も復元せず，母相中の固溶 $\mathrm{Mg}, \mathrm{Si}$ 量を減少させることで強化 相である $\beta^{\prime \prime}$ 相の数密度の低下, 二段時効の負の効果を引き 起こすのに対し，クラスタ（2）は拡散律速による成長の容 易さ，および $\beta^{\prime \prime}$ 相との組成の類似性から， $\beta^{\prime \prime}$ 相へと連続的 に遷移することが示唆された ${ }^{10)}$ 。このようなナノメートル オーダでの化学分析も3DAPの強みのひとつであり, 組成や サイズに起因するナノクラスタの熱的安定性や $\beta^{\prime \prime}$ 相への遷 移のしやすさの違いによって，本系合金の複雑な多段時効硬 化挙動が説明できるものと考えている。

\section{4. $3 \mathrm{Al}-\mathrm{Mg}-\mathrm{Cu}(-\mathrm{Ag})$ 合金のナノ組織解析}

$\mathrm{Al}-\mathrm{Mg}-\mathrm{Si}$ 系合金と並んで自動車用ボディパネル材料とし て使用されている $\mathrm{Al}-\mathrm{Mg}$ 合金に, $\mathrm{Cu}$ および微量の $\mathrm{Ag}$ を添加 すると, BH性を付与, 向上させることが可能である。これ は, 結晶粒界や転位上に不均一析出する $\mathrm{S}^{\prime}-\mathrm{Al}_{2} \mathrm{CuMg}$ 相に代 わって，粒内に粒状の Z- $\mathrm{AlMgCuAg}$ 相が微細分散するため であり，相分解初期に形成するナノクラスタと梁く関連して いる ${ }^{12)}$ 。

図 10 は， $\mathrm{Al}-3 \% \mathrm{Mg}-1 \% \mathrm{Cu}-0.4 \% \mathrm{Ag}$ 合金の溶体化・焼入れ まま（A.Q.）およびベークハード温度である $443 \mathrm{~K} て ゙$ 種々の 時間時効した際のアトムマップである。三元合金とは異な り，1.8または $3.6 \mathrm{ks}$ という短時間時効でも $3 \sim 4 \mathrm{~nm}$ 程度のナ ノクラスタが明瞭に観察され， $\mathrm{Ag}$ 添加によってクラスタ形 成が著しく促進されることがわかる ${ }^{12)}$ 。また, クラスタの 組成についても, 時効初期では $\mathrm{Cu}$ より $\mathrm{Mg}$ や $\mathrm{Ag}$ 濃度の方 が高く，主に $\mathrm{Mg} / \mathrm{Ag}$ クラスタが形成しているのに対し，時 効時間が経過すると次第に $\mathrm{Cu}$ 原子が取り达まれて $\mathrm{Mg} / \mathrm{Cu} / \mathrm{Ag}$ クラスタ, そして Z相へと相分解することが明らかとなっ た (図 11) ${ }^{12)}$ 。この Ag を含むナノクラスタは, Z相の優先核 生成サイトとして働き, $\mathrm{Z}$ 相の数密度の増加が $\mathrm{Ag}$ 添加合金 の著しい硬化を引き起こしたものと考えられる。なお，この ような $\mathrm{Ag}$ 原子の特徵的な挙動は, 著者らが提案する「相互 作用エネルギーマップ」 ${ }^{13)}$ によって説明でき，マイクロアロ イングによるアルミニウム合金の特性改善の好例となってい る。

\section{$4.4 \mathrm{Al}-\mathrm{Ni}-\mathrm{Gd}$ 系金属ガラスのナノ組織解析}

メルトスピニング法によって作製された $\mathrm{Al}-\mathrm{Ni}-\mathrm{Gd}$ 系金属 ガラスは，冷却速度や合金組成に依存して複雑なナノ組織を もつことが知られている ${ }^{14)}$ 。図 12 は, $\mathrm{Al}_{90} \mathrm{Ni}_{3} \mathrm{Gd}_{7}$ 合金単ロー ルメルトスパンリボン材（冷却速度〜 $10^{6} \mathrm{~K} / \mathrm{s}$, 膜厚〜 $25 \mu \mathrm{m}$ ) の高分解能透過電顕 (HRTEM) 像および2つの異なる視野 から得られた対応するFFT像である ${ }^{15)}$ 。 HRTEM像で maze コントラストを呈する視野からは, アモルファス構造に特 有なハローパターンをもつFFT像が得られ (図 $12(\mathrm{~b})$ ), 一方 HRTEM像で輝点の配列に周期性が見られる視野からは, fcc $\alpha-\mathrm{A} 1$ 相に対応する回折スポットをもつ FFT像が得られた（図 $12(\mathrm{c}))$ 。これは, アモルファス母相中に $\alpha-\mathrm{Al}$ 相粒子が微細分 散していることを示唆しており, 得られたナノ組織の詳細, 例えばナノ結晶粒子の形状やサイズ，分布状態， Niや $\mathrm{Gd}$ の 偏析挙動などの知見が求められていた。

図 13 に，同じメルトスパンリボン材の3DAP分析結果 ${ }^{15}$ を示す。図 $13(\mathrm{a}),(\mathrm{b})$ のアトムマップからはNiおよび $\mathrm{Gd}$ 原 子の空間的な偏りを確認することは困難であるが, 図 13 (c) の等濃度曲面表示によって, 数nmのサイズをもつ $\mathrm{Al}$ 濃度の 高い粒子が試料内に高密度に分布していることが明らかに なった。HRTEM観察結果（図 12）との比較から，このナノ 粒子は $\alpha-\mathrm{Al}$ 相であると考えられ, 内部には平衡濃度よりは多 量であるが，バルク組成よりは少量の〜 $1 \mathrm{at} \% \mathrm{Ni}, \sim 4 \mathrm{at} \% \mathrm{Gd}$ が固溶していることがわかった（図 $13(\mathrm{e}))$ 。一方，ナノ結 晶粒子を取り囲むアモルファス母相（図 13(d)）には, 逆に ナノ結晶粒子から排出された $\mathrm{Ni}$ や Gdが濃縮し, アモルファ ス母相との界面に高濃度に偏析することが確かめられた（図 13 (e) 矢印)。このように, HRTEM観察を併用することで, 3DAPの分析結果を解釈する際に必要となる相同定に関する 
(a)
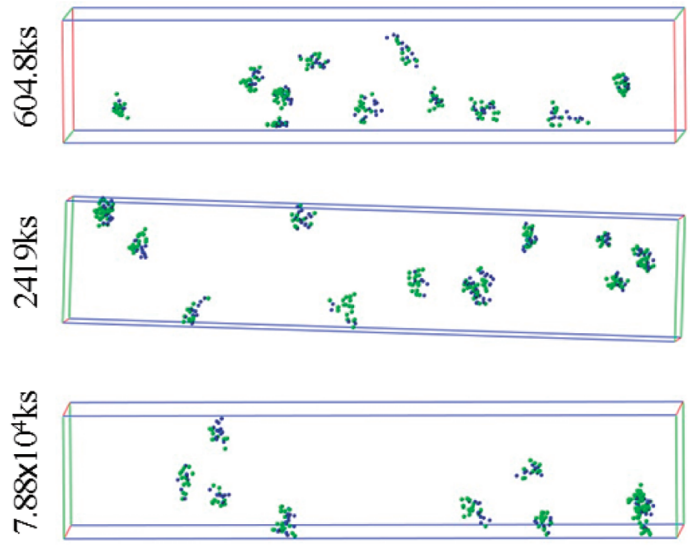

(b)
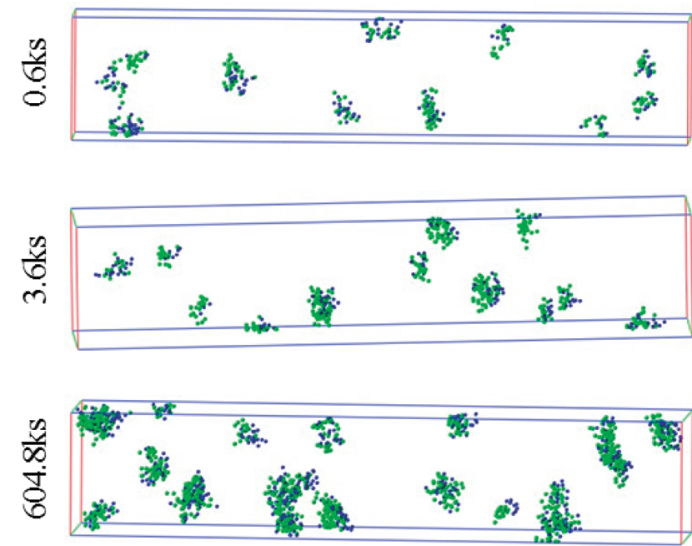

$\overline{5 \mathrm{~nm}}$

図8 過剩 $\mathrm{Si}$ 型 $\mathrm{Al}-\mathrm{Mg}-\mathrm{Si}$ 合金を室温（a）拈よび $373 \mathrm{~K}$ (b) で各時間時効した際のアトムマップ10)。クラスタ解析後のナ ノクラスタの分布を $\mathrm{Mg}, \mathrm{Si}$ 原子をそれぞれ緑点, 青点として示す
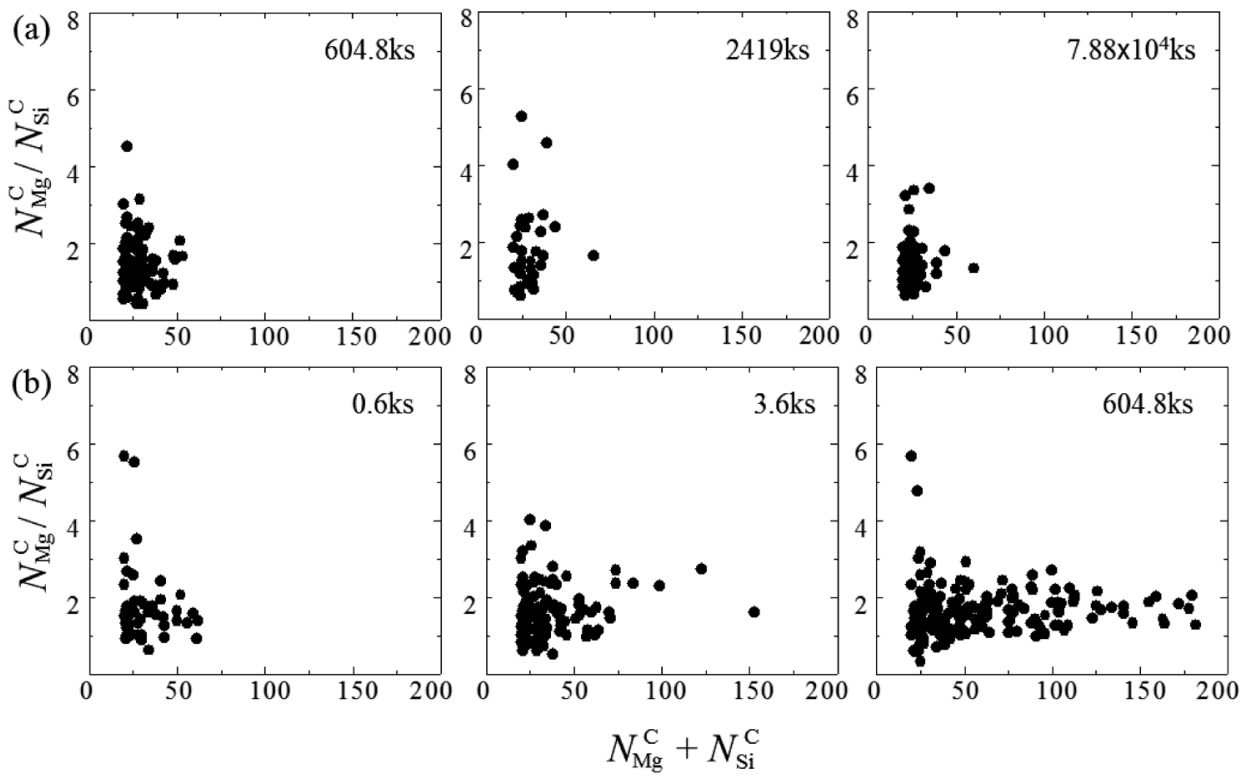

図9 過剩 $\mathrm{Si}$ 型 $\mathrm{Al}-\mathrm{Mg}-\mathrm{Si}$ 合金を室温（a）および $373 \mathrm{~K}$ （b）で各時間時効した際に形成するナノクラスタの組成（ $\left.N_{\mathrm{Mg}}^{\mathrm{c}} / N_{\mathrm{Si}}^{\mathrm{c}}\right)$ ならびにサイズ $\left(N_{\mathrm{Mg}}^{\mathrm{c}}+N_{\mathrm{Si}}^{\mathrm{c}}\right)$ 分布 ${ }^{10)}$

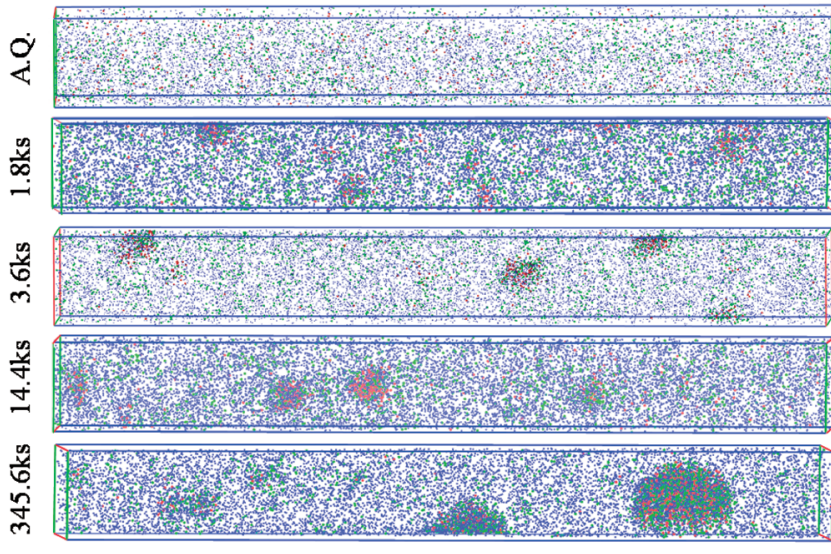

$\overline{5 \mathrm{~nm}}$

図 $10 \mathrm{Al}-\mathrm{Mg}-\mathrm{Cu}-\mathrm{Ag}$ 合金を $443 \mathrm{~K} て ゙$ 各時間時効した際 のアトムマップ ${ }^{12)}$ 。 $\mathrm{Mg}, \mathrm{Cu}, \mathrm{Ag}$ 原子をそれぞれ 青点, 緑点, 赤点で表す
情報を引き出すことができ, アルミニウム合金中のナノ組織 解析をより高度に行うことが可能である。

\section{4. $5 \mathrm{Al}-\mathrm{Zn}-\mathrm{Mg}$ 合金の結晶粒界近傍のナノ組織解析}

熱処理型アルミニウム合金では, 粒内に析出相が微細分散 する時効処理条件であっても, 結晶粒界近傍ではほとんど析 出が起こらない無析出帯 (precipitate free zone, 以下 PFZと呼 ぶ）が形成することがある。図 14は，Al-2 at \% Zn-1.9 at \% Mg 合金を $433 \mathrm{~K}$ で時効した際の結晶粒界近傍の TEM組織, およ び粒内ならびにPFZ内部のナノインデンテーション硬さを示 $す^{16)}$ 。時効時間の経過とともに, 粒内では $\eta^{\prime} / \eta$ 相の析出・成 長によって硬さの増加および減少が生じるのに対し, PFZ内 部では時効初期から単調に軟化することがわかる。この理由 としては, 粗大な安定相の粒界析出によって, 結晶粒界近傍 の溶質原子濃度が減少し, 固溶強化の寄与が低減したことが 挙げられるが (溶質枯渇説), 粒界析出が顕著でない時効初 期に形成する PFZについては不明な点が多かった。 


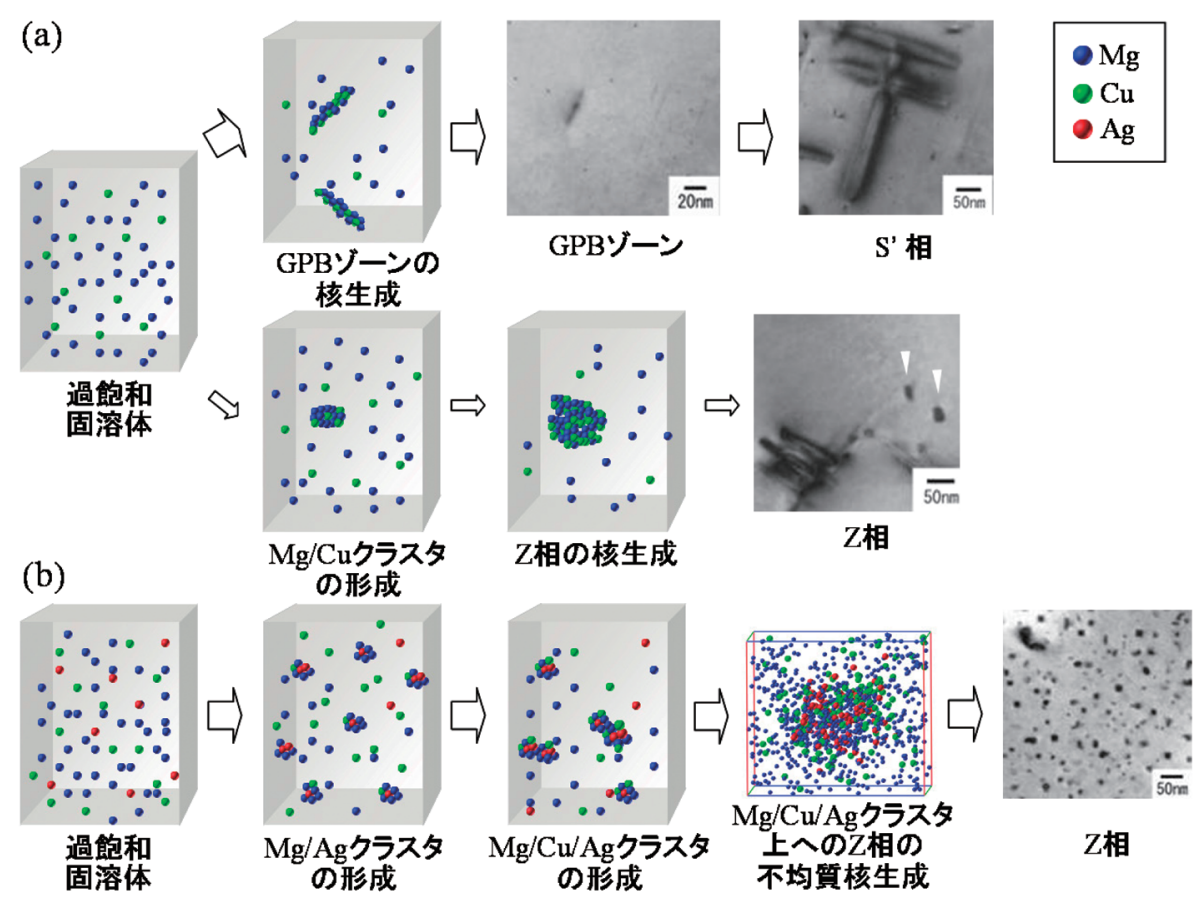

図 $11 \mathrm{Al}-\mathrm{Mg}-\mathrm{Cu}$ 合金（a）および $\mathrm{Ag}$ 添加合金（b）の相分解過程の模式図 ${ }^{12 ）}$
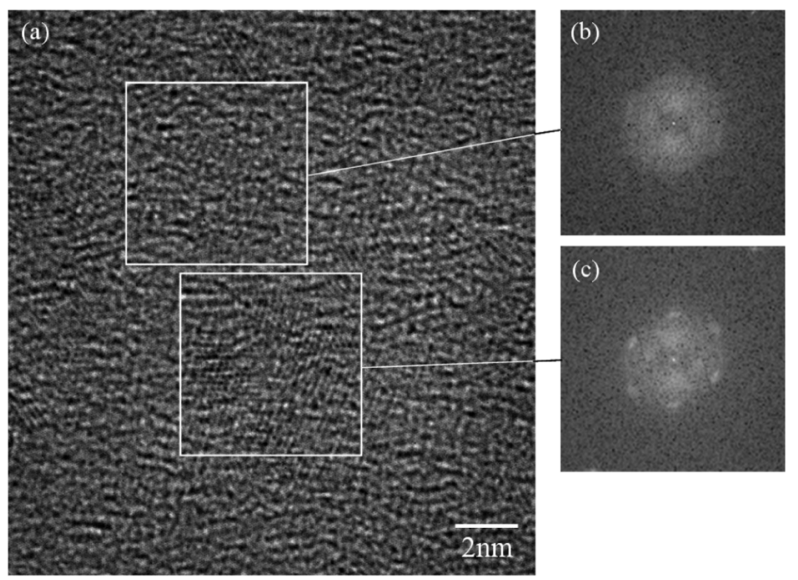

図 $12 \quad \mathrm{Al}_{90} \mathrm{Ni}_{3} \mathrm{Gd}_{7}$ 合金メルトスパン材の HRTEM 像と 2 つの異なる視野から得られた対応する FFT 像 ${ }^{15)}$

図 15 に, 同じ合金を $433 \mathrm{~K} て ゙ 3.6 \mathrm{ks}$ 時効後, 針状試料先端 に結晶粒界およびPFZを配置してから3DAP分析を行った結 果を示す ${ }^{17)}$ 。結晶粒界に最も近い粒内析出相の位置ならび に分析開始・終了時点の針状試料の形状から，本分析が結晶 粒界から 342〜384nm離れたPFZ内部で行われたことが確か められ，分析体積内の $\mathrm{Zn}$ および $\mathrm{Mg}$ 濃度もバルク組成のそれ とほぼ同程度であることがわかった（図15(a)，(b))。そこで, maximum separation 法 $^{11)}$ を用いたクラスタ解析を行ったとこ 万, 約 15 個程度の $\mathrm{Zn}+\mathrm{Mg}$ 原子からなるナノクラスタが高密 度に検出され（図15(c)), しかも結晶粒界に近づくほどそ

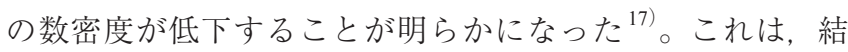
晶粒界が焼入れ過剩空孔の消滅サイトとして働き, 結晶粒界 に近いほど溶質原子の拡散や析出相の形成が遅滞したためと 考えられるが (空孔枯渇説), PFZと呼ばれる領域であって もナノクラスタは高密度に形成することは, 本解析によって 初めて明らかになった知見である。 (a)
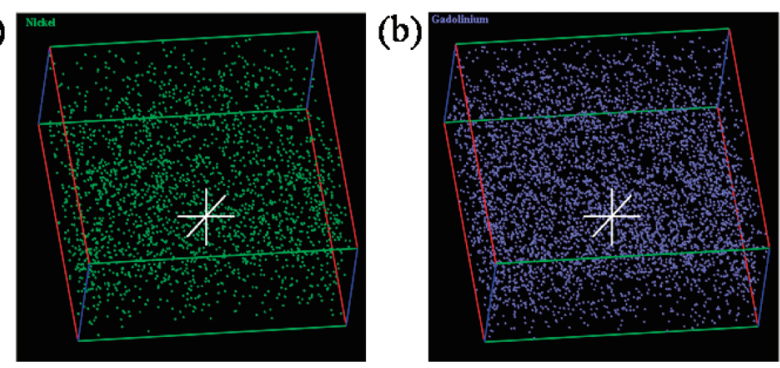

(c)

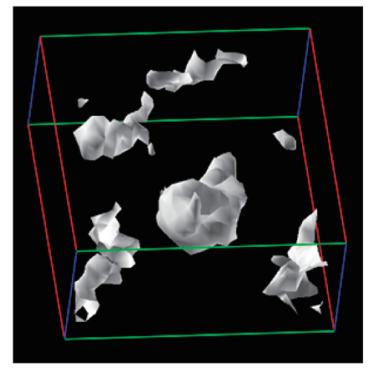

(d)

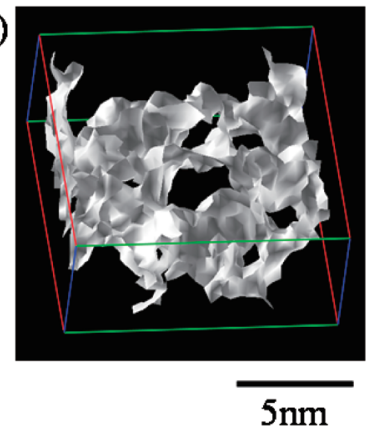

(e)

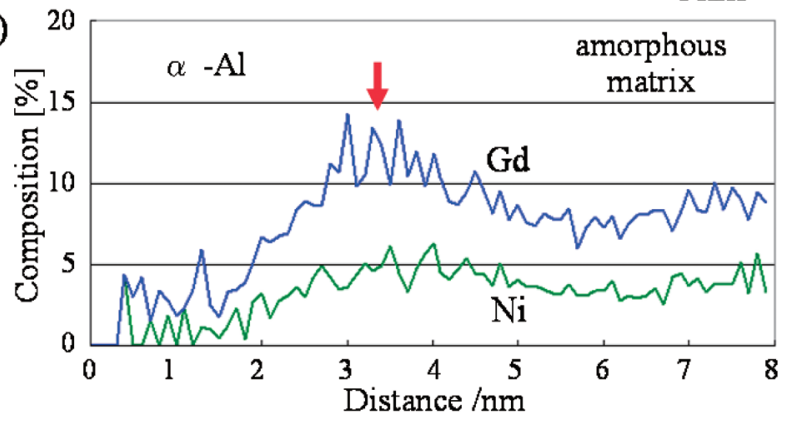

図 $13 \mathrm{Al}_{90} \mathrm{Ni}_{3} \mathrm{Gd}_{7}$ 合金メルトスパン材の3DAP分析結果。 (a)，(b) Ni および Gd原子のアトムマップ，（c）， (d) 4 および $14 \mathrm{at} \%$ （Ni+Gd）における等濃度曲 面, (e) $\alpha-\mathrm{Al}$ 相粒子中心から動径方向の濃度プ ロファイル ${ }^{15)}$ 
G.B.
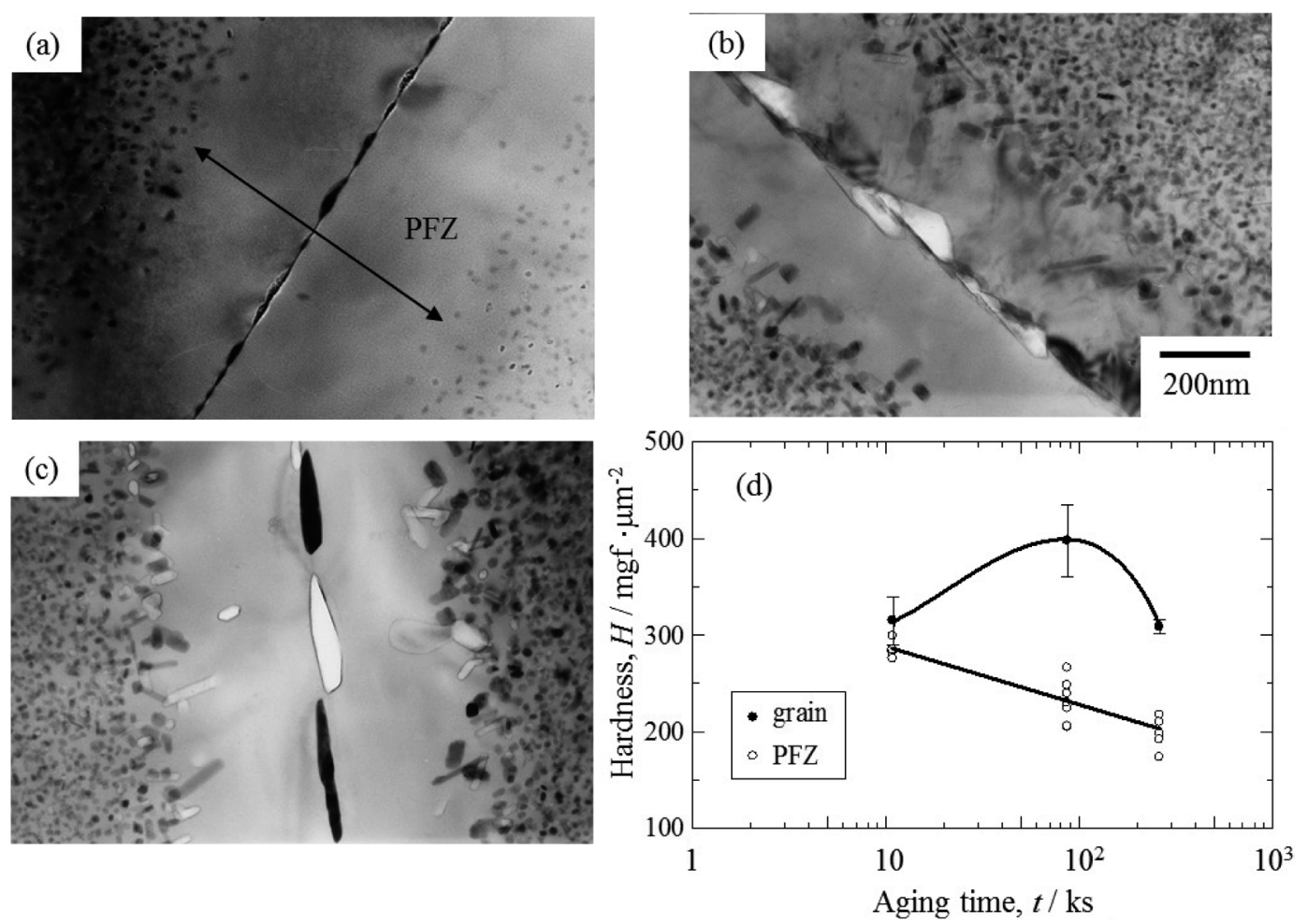

図 $14 \mathrm{Al}-2 \mathrm{at} \% \mathrm{Zn}-1.9 \mathrm{at} \% \mathrm{Mg}$ 合金を $433 \mathrm{~K} て ゙ 10.8 \mathrm{ks} \quad(\mathrm{a}), 86.4 \mathrm{ks} \quad(\mathrm{b}), 259.2 \mathrm{ks}$ （c）時効した際の結晶粒界近傍における TEM 組織。ナノインデンテーションで測定した粒内およびPFZ内部の硬さ変化（d）も合せて示す ${ }^{16)}$

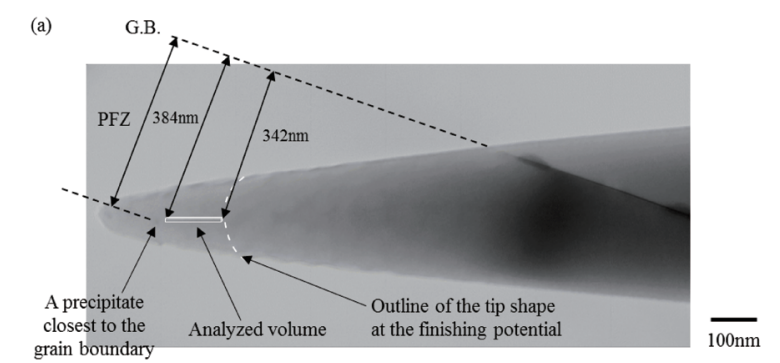

(b)

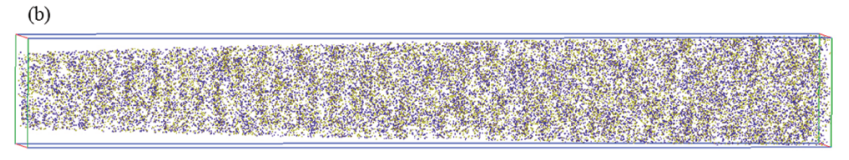

(c)

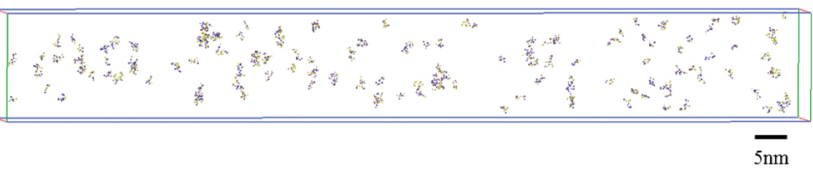

図 $15433 \mathrm{~K}$ で $3.6 \mathrm{ks}$ 時効した Al-2 at $\% \mathrm{Zn}-1.9 \mathrm{at} \% \mathrm{Mg}$ 合 金の結晶粒界近傍における TEM組織（a）。針状 試料中の白枠で示した分析体積内のアトムマッ プ（b）およびクラスタ解析後のナノクラスタの 分布（c）も Zn, Mg 原子をそれぞれ黄点, 青点と して表す ${ }^{17)}$

\section{5. おわりに}

3DAP分析は，これまで装置の開発に携わってきた少数の 大学や企業, 研究所などに所属する研究者の独壇場といっ た䨌囲気があったが, 最近は装置の自動化や簡易化などが進 み, 一般ユーザーが先端分析機器の一つとして気軽に利用で
きるまでになってきた。また，アトムプローブ分析の弱点と いわれた「分析領域の小ささ」や「非導電性試料の分析」に 関しても, 近年開発された広角型アトムプローブやレーザー

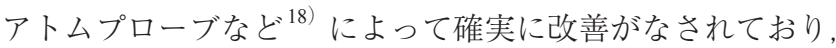
本手法のさらなる発展が期待されている。本稿が, 新しい 3DAPユーザーの一助になれば幸いである。

なお, 本研究の一部は, 新エネルギー・産業技術総合開発 機構（NEDO）「実用金属材料分野ナノメタル技術開発プロ ジェクト」の一環として行われた。付記して謝意を表する。

\section{参考 文 献}

1) A. Cerezo, T. J. Godfrey and G. D. W. Smith: Rev. Sci. Instrum., 59 (1988), 862-866.

2) M. K. Miller and G. D. W. Smith: Atom Probe Microanalysis: Principles and Applications to Materials Problems, Materials Research Society, Pennsylvania, (1989), 1.

3) M. K. Miller: Atom Probe Tomography: Analysis at the Atomic Level, Kluwer academic/Plenum publisher, New York, (2000), 38.

4) 宝野和博, 弘津禎彦: 金属ナノ組織解析法, アグネ技術セン 夕一, 東京, (2006), 235.

5) A. Cerezo, D. J. Larson and G. D. W. Smith: MRS Bull., 26 (2001), 102-107.

6) 高橋 淳, 川上和人, 小林由紀子, 山田淳一：新日鉄技報, 390 (2010), 20-27.

7) D. Blavette, F. Vurpillot, P. Pareige and A. Menand: Ultramicroscopy, 89 (2001), 145-153.

8）小宮良樹, 廣澤涉一, 里 達雄：軽金属, 56 (2006), 662-666.

9) 山田健太郎, 里 達雄, 神尾彰彦 : 軽金属, 51 (2001), 215221.

10) A. Serizawa, S. Hirosawa and T. Sato: Metall. Mater. Trans., 39A (2008), 243-251.

11) D. Vaumouse, A. Cerezo and P. J. Warren: Ultramicroscopy, 95 (2003), 215. 
12）廣澤渉一, 大村知也, 里 達雄, 鈴木義和：軽金属, 56 (2006), 673-679.

13）廣澤渉一, 中村文滋, 里 達雄, 星野敏春: 軽金属, 56 (2006), 621-628.

14) F. Q. Guo, S. J. Poon and G. J. Shiflet: Scr. Mater., 43 (2000), 10891095.

15）廣澤涉一：軽金属学会第112回春期大会講演概要, (2007),
$21-22$.

16) T. Ogura, S. Hirosawa and T. Sato: Sci. Technol. Adv. Mater., 5 (2004), 491-496.

17) T. Ogura, S. Hirosawa, A. Cerezo and T. Sato: Acta Mater., 58 (2010), 5714-5723.

18) T. F. Kelly and D. J. Larson: Annu. Rev. Mater. Res., 42 (2012), 1-31. 